\title{
E-Devlet Kapısını Kullanmayı Etkileyen Faktörlerin Araştırılması
}

\author{
Kamil Çelik ${ }^{*}$, Mehmet Orhan ${ }^{2}$

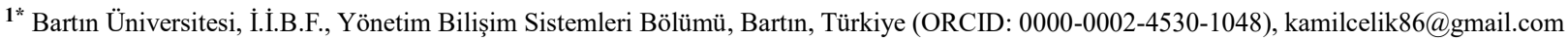 \\ ${ }^{2}$ Niğde Ömer Halisdemir Üniversitesi, Niğgde Sosyal Bilimler MYO, Yönetim ve Organizasyon Bölümü, Niğge, Türkiye, (ORCID: :0000-0003-1160-0258), \\ mehmetorhan01@gmail.com
}

(İlk Geliş Tarihi 16 Temmuz 2021 ve Kabul Tarihi 6 Aralık 2021)

(DOI: 10.31590/ejosat.972584)

\begin{abstract}
ATIF/REFERENCE: Çelik, K. \& Orhan, M. (2021). E-Devlet Kapısını Kullanmayı Etkileyen Faktörlerin Araştırılması. Avrupa Bilim ve Teknoloji Dergisi, (31), 212-222.
\end{abstract}

\section{Öz}

Teknoloji alanında son yıllarda ortaya çıkan gelişmeler internet kullanım oranlarını artırmıştır. Vatandaşların kamu yönetimlerinden beklentileri hem artmış hem de farklılaşmıştır. Bu bağlamda kamu yönetimleri internet tabanlı teknolojileri daha fazla kullanmaya başlamıştır. Böylece E-devlet kapısı ortaya çıkmış ve kullanımı giderek yaygınlaşmıştır. Günümüzde birçok vatandaş E-devlet kapısı vasıtasıyla kamusal işlemlerini gerçekleştirmektedir. Bu çalışmada teknoloji kabul modeline yeni değişkenler eklenerek E-devlet kapısını kullanmayı etkileyen faktörler araştırılmıştır. Modelde algılanan fayda, algılanan kullanım kolaylı̆̆ı, bilgi kalitesi, sistem kalitesi, kişilerarası etki ve dış etkinin kullanıcı tatmini üzerindeki etkisi, kullanıcının tatminin de E-devlet sistemini kullanmaya devam etme niyeti üzerindeki etkisi araştırılmıştır. Bunun için 1427 E-devlet sistemi kullanıcısına yönelik bir araştırma yapılmıştır. Veriler yapısal eşitlik modeli ile analiz edilmiştir. Analiz sonuçlarına göre algılanan fayda, algılanan kullanım kolaylığı, bilgi kalitesi, kişilerarası etki ve dış etki kullanıcı tatmini üzerinde anlamlı ve pozitif bir etkiye sahip olduğu, sistem kalitesinin ise tatmin üzerinde anlamlı bir etkisinin olmadığı görülmüştür. Ayrıca kullanıcı tatmininin E-devlet sisteminin kullanmaya devam etme niyetini anlamlı ve pozitif olarak etkilediği tespit edilmiştir.

Anahtar Kelimeler: E-devlet, Teknoloji Kabul Modeli (TKM), Bilgi Sistemi, Davranışsal Niyet.

\section{Investigation of the Factors Affecting Using the E-Government Portal}

\begin{abstract}
Developments in the field of technology in recent years have increased the rate of internet usage. Citizens' expectations from public administrations have both increased and differentiated. In this context, public administrations have started to use internet-based technologies more. Thus, the e-government door emerged and its use has become increasingly widespread. Today, many citizens carry out their public transactions through the e-government portal. In this study, new variables were added to the technology acceptance model and the factors affecting the use of the e-government door were investigated. In the model, the effect of perceived usefulness, perceived ease of use, information quality, system quality, interpersonal influence and external influence on user satisfaction, and the effect of user satisfaction on the intention to continue using the e-government system were investigated. For this purpose, research was conducted on 1427 e-government system users. The data were analyzed with the structural equation model. According to the results of the analysis, it was seen that perceived usefulness, perceived ease of use, information quality, interpersonal influence, and external influence had a significant and positive effect on user satisfaction, while system quality did not have a significant effect on satisfaction. In addition, it has been determined that user satisfaction significantly and positively affects the intention to continue using the egovernment system.
\end{abstract}

Keywords: E-Government, Technology Acceptance Model (TAM), Information System, Behavioral Intention.

* Sorumlu Yazar: kamilcelik86@gmail.com 


\section{Giriş}

Bilgi iletişim teknolojilerinin hızla gelişmesiyle beraber ortaya çıkan dijital devrim sadece insanların günlük hayatlarını değiştirmekle kalmamış, aynı zamanda özel işletmeler ile vatandaş ve devlet ile vatandaşlar arasındaki iletişim ve etkileşim özelliklerini de değiştirmiştir (Acılar, 2015). Türkiye'de de internet kullanımının yaygınlaşmaya başlanmasıyla beraber bilgi toplumu ve bilgiye dayalı ekonomi kavramların tanımlanmasıyla ilgili çalışmalara önem verilmiştir. $\mathrm{Bu}$ dönemde internetin sağladığı fayda ve firsatlar özellikle özel işletme ve organizasyonlarca fark edilmesiyle beraber bu özel işletme ve organizasyonlarca internet siteleri oluşturulmaya başlanmıştır. Internet'in topluma hizmet sağlamada iyi bir araç olarak kullanabileceği Kamu Kurumları tarafindan da fark edilmesiyle, bu kurumlar da kendi internet sitelerini oluşturmaya başlamıştır. $\mathrm{Bu}$ dönemde kurulan internet siteleri önceleri sadece bilgilendirme maksadıyla oluşturulmuşken daha sonra değişim geçirerek hizmet verme amacı gütmeye başlamıştır (Naralan, 2009:5). Bu dönemde kurumların internet siteleri arasında uyum olmaması ve E-devlet uygulamaları ile ilgili koordinasyon ve entegrasyon ihtiyacının giderilememiş olması bazı problemleri de beraberinde getirmiştir. Birçok kurum çerçevesinde çok sayıda proje uygulanmaktayken, bütünleşmiş bir sistem geliştirilememiştir (Yavuz ve Çarıkçı, 2009: 13). 2001 ve sonraki yıllardan itibaren internet sitelerince sağlanan kamusal hizmetlerin koordinasyon kolaylığının sağlanması için tek noktadan- yürütülmesi görüşü kabul görmüştür (Akçakaya, 2017: 18). Bunun sonucu olarak literatürde "E-devlet" olarak ifade edilen "E-devlet Kapısı Projesi” ortaya çıkmıştır.

Türkiye'de 18 Aralık 2008'de "E-devlet Kapısı Projesi" hizmete açılmasıyla birlikte tüm E-devlet uygulamaları tek çatı altında yürütülmeye başlamıştır. E-devlet hizmetlerinin tümüne birden ulaşmayı sağlayan 'E-devlet kapısında yar alan tanıma göre E-devlet, tüm kamu hizmetlere tek merkezden ulaşma olanağı sunan büyük ve kapsamlı bir internet sitesidir. Bu bağlamda E-devlet Kapısı'nın temel hedefi kamusal hizmetlerin, vatandaş(lar)a, işletmelere, kurum ve kuruluşlara bilgi ve iletişim teknolojileri ile verimli ve etkin bir biçimde sunulması olarak gösterilebilir (Türkiye Cumhuriyeti Cumhurbaşkanlığg Dijital Dönüşüm Ofisi-Projeler, t y ).

E-devlet sistemiyle tüm elektronik devlet hizmetlerinin kesintisiz çalışabilmesi; zaman ve enerji kaybı minimum düzeye indirilmesi hedeflenmiştir. E-devlet projesi kapsamında ilk etapta 22 kamu hizmetine erişim yapılıp (Yavuz ve Çarıkçı, 2009: 13) ve yaklaşık 10000 kullanıcısı bulunmaktayken; 20/12/2020 tarihi itibariyle 51.856.543 kayıtlı kullanıcı bulunmakta ve 702 kuruma ait 5.377 hizmete ulaşılabilmektedir. Türkiye'nin nüfusunun yaklaşık 82 milyon olduğu düşünüldüğünde nüfusun yarıdan fazlası E-devlet kayıtlı kullanıcısı konumundadır (TUIK, t.y.). Bu hizmetlerin neredeyse tamamina kullanıcılar "http://www.turkiye.gov.tr" adresi aracılığıyla kolaylıkla erişebilmektedir. Böylelikle bu internet sitesiyle çok sayıda kamu hizmetine tek çatı altında tek adresten ulaşabilme imkânı sunulmaktadır (Yavuz ve Çarıkçı, 2009: 13). Bilgi toplumuna hazırlık açsından Türkiye'nin e- devlet uygulamaları, uluslararası kuruluşlar tarafindan açıklanan raporlarda Dünya sıralaması bakımından ortalamanın üzerinde sırada yer almaktadır. Ayrıca raporda Türkiye'nin telekomünikasyon altyapı alanında göstermiş olduğu başarılardan övgüyle bahsedilmiş ve verilen hizmetlerin diğer ülkelere kıyasla ucuz olduğu vurgulanmıştır (Taytak ve Vural, 2019, 68-69).

Literatür taraması sonucunda Türkiye'nin E-devlet sistemiyle ilgili olarak vatandaşların sisteminden memnuniyetleri ve onları sistemi kullanmaya iten faktörlerin belirlenmesine yönelik çalışmaların az sayıda olduğu görülmüştür. $\mathrm{Bu}$ nedenle çalışmada Türk vatandaşlarının E-devlet sisteminden memnuniyetlerini ve onları kullanmaya iten faktörlerin neler olduğunun araştırılması amaçlanmıştır. Ayrıca bu çalışmayla literatüre katkı sağlanması hedeflenmiştir. Çalışma vatandaşların E-devlet sisteminin kabulünü etkileyen faktörlerin neler olduğunu göstermesi açısından karar vericiler ve araştırmacılara yol gösterici bir özellik taşımaktadır. Ayrıca bu çalışmayla literatüre katkı sağlanması hedeflenmiştir.

\section{Teorik Arkaplan}

$\mathrm{Bu}$ bölümde Türkiye'de E-devlet kapısı sistemi incelenecektir. Ayrıca çalışmada temel alınan teknoloji kabul modeline değinilecektir.

\subsection{Türkiye'de E-devlet uygulamaları}

E-devlet, devlet kurumlarının, özel sektör çalışanları, devlet çalışanları, vatandaş ve diğer devlet kurumlarıyla elektronik biçimde bağlantılı olmasıyla oluşan; emek, zaman ve maddi tasarruflar yapılmasına olanak sağlayan, performans, etkinliği ve verimlilik artışını sağlayan organizasyonel bir sistem olarak tanımlanmaktadır (Akçakaya, 2017: 9). Literatürdeki birçok istatistiksel çalışmada E-devletin yolsuzluğu azaltma ve bürokratik verimliliği artırma yeteneğini ortaya konmuştur (Schopf, 2020).

Türkiye'de E-devlet uygulamalarının başlangıcına yönelik olarak farklı görüşler bulunmaktadır. $\mathrm{Bu}$ görüşlerden ilki, Türkiye'de E-devletin temellerinin, 1934 yılında T.C. Ziraat Bankası'nda kullanılmaya başlanan delikli kart sistemiyle çalışan büro makineleriyle başladığını savunan görüştür (Kılıççeken, 2019). Diğer bir görüşe göre ise Türkiye'de E-devlet uygulamalarının geçmişi, 1982 'de projelendirilen Merkezi Nüfus İdaresi Projesi (MERNISS) projesi ile ilk çalışmaları 1985 yılında başlayan ve Maliye Bakanlığı tarafından kullanılan Saymanlık Otomasyon projesi (SAYOTO)'dur (Naralan, 2009:5; Demirhan ve Türkoğlu, 2014: 241). İlerleyen yıllarda Türkiye'de, birçok isim altında bilgi toplumuna geçiş amacıyla bu çalışmalara benzer birçok çalışma yapılmıştır. Bu projeler yoğun emek ve zaman isteyen bazı iş ve işlemlerin, bilgisayar kullanılarak kolaylaştırılması için başlatılmıştır. Bu dönemlerde internetin yaygın olmaması nedeniyle bu sistemleri kullanmaktaki temel amaç, yığın bilgilerin kolayca işlenmesi ve saklanmasıydı. Bu bağlamda gerçekleştirilen bu sistem ve çalışmaları, günümüzün E-devlet uygulamalarından farklı otomasyon çalışmaları olarak değerlendirilmektedir (Naralan, 2009:5; Demirhan ve Türkoğlu, 2014: 241).

E-Devlet Kapısı Projesiyle öncelikli olarak, işletmelere, vatandaşlara ve kamu kurum kuruluşlarına bilgi ve iletişim teknolojilerinden faydalanılarak nitelikli, kaliteli, verimli ve etkin biçimde hizmetlerin sağlanması hedeflenmektedir. Birçok gelişmiş ülkelerdeki örneklerinde olduğu gibi E-Devlet Kapısı Projesi devlet- iş- vatandaş olmak üzere üç ana bölüm biçiminde hizmet sunmaktadır (Yavuz ve Çarıkçı, 2009: 13). Şu anda elektrik, doğalgaz aboneliğinden üniversite ön kayıt işlemlerine kadar birçok kamu hizmetine erişim E-devlet ile kolayca 
yapılabilmektedir. Önümüzdeki yıllarda tüm kamu hizmetlerine yönelik erişimlerin E-devlet üzerinde kolayca yapılabilmesi hedeflenmektedir.

Literatürdeki bazı çalışmalardaki ampirik bulgular, Türkiye'de E-devlet hizmetlerinin kullanımında cinsiyet farklılığı olduğunu göstermektedir. Türk kadınlarının türk erkeklerine kıyasla E-devlet araçlarını kullanma olasılığı daha düşüktür. Hane halk1 geliri, eğitim düzeyi, istihdam ve internet kullanım sıklı̆̆ı, Türk bireyler için E-devlet kullanımı olasılığı ile pozitif ilişkilidir. Son olarak, yaş çevrimiçi devlet hizmetlerinin kullanımı ile negatif bir ilişki olduğunu göstermektedir. Birey yaşlandıkça, Edevlet platformlarını kullanma olasılığı azalmaktadır (Kose, 2019). Bu nedenle bilgisayar kullanma becerisi yeterli düzeyde olmayan veya herhangi bir sebeple E-devlete erişme problemi yaşayanlar için banka şubelerine benzer E-devlet erişim büroları kurularak E-devlet hizmetlerine kolaylıkla erişimlerinin sağlanması hedeflenmektedir. $\mathrm{Bu}$ hedefe yönelik olarak Türkiye'de elektronik hizmetlere erişim imkânı olmayan vatandaşların dijital hizmetlere erişiminin sağlanması amacıyla kullanıcıyı merkezine alan hizmet sunumunun sağlanması bakış açısıyla "Tek Durak Hizmet Noktası" projesi başlatılmıştır. Bu projeyle hizmet sunum kanalları iyileştirilerek çeşitliliği arttırılacaktır. Böylece dezavantajlı kesimler başta olmak üzere tüm vatandaşların kolaylıkla tüm kamu hizmetlerine ulaşabilmesinin sağlanması amaçlanmaktadır. "Tek Durak Hizmet Noktası" projesinin benzer örnekleri incelendiğinde Edevlet portali benzeri yapılarla beraber fiziksel erişimin de mümkün olduğu Tek Durak noktalarından oluştuğu görülmektedir. Böylelikle hem elektronik kanallardan erişimin hem de fiziksel "Tek Durak" noktalarından hizmet sunumun sağlanmasıyla, eşit şartlarda tüm vatandaşların kolaylıkla kamu hizmetlerine ulaşabilmeleri sağlanacaktır (Türkiye Cumhuriyeti Cumhurbaşkanlığı Dijital Dönüşüm Ofisi-Projeler, $\mathrm{t} \mathrm{y}$ ). Günümüzde Türkiye'de en çok dikkat çeken E-devlet uygulamaları şunlardır (Taytak ve Vural, 2019, s. 70):

- E-devlet kapısı portalı

- Vergi Dairesi Otomasyon Projesi (VEDOP)

- Gümrük İdaresinin Modernizasyonu (GİMOP)

- Merkezi Nüfus İdaresi Sistemi (MERNIS)

- $\quad$ Polis Bilgi Ağı Projesi (POLNET)

- Ulusal Yargı Ağı Projesi (UYAP)

- Tapu ve Kadastro Bilgi Sistemi Projesinin (TAKBİS)

- Motorlu Taşıtlar Otomasyon Projesi (MOTOP)

- Say2000 Web Tabanlı Saymanlık Otomasyon Projesi

- Milli Emlak Otomasyon Projesi (MEOP)

En çok kullanılan E-devlet hizmetleri sırasıyla: 4A Hizmet Dökümü (Sosyal Güvenlik Kurumu Sosyal Güvenlik Kurumu), Dava Dosyası Sorgulama (Adalet Bakanlığı), Sosyal Güvenlik Kurumu Tescil ve Hizmet Dökümü (Sosyal Güvenlik Kurumu ), Vergi Borcu Sorgulama (Gelir İdaresi Başkanlığg) Araç Plakasına Yazılan Ceza Sorgulama (Emniyet Genel Müdürlüğü ) Gençlik ve Spor Bakanlığı Gençlik ve Spor Bakanlığı Yurt Başvurusu şeklindedir (Türkiye Cumhuriyeti Cumhurbaşkanlığı Dijital Dönüşüm Ofisi-En Çok Kullanılan Hizmetler, t y ).

\subsection{Teknoloji Kabul Modeli}

İnsanların teknolojiyi kabulü ve benimseme ile konusundaki niyetlerini araştırmak için literatürde birçok model ve(ya) teori sunulmuştur (Al-Emran, Mezhuyev ve Kamaludin, 2018; Lai, 2017; Rafique, Almagrabi, Shamim, Anwar ve Bashir, 2020). Bu modellerden birisi de Teknoloji Kabul Modeli (TKM) dir. TKM ilk olarak Davis (1986) tarafindan yapılan çalışmada ortaya konmuştur. TKM, sonrasında Davis, Bagozzi ve Warshaw (1989) tarafından yapılan çalışmada daha geliştirilerek modifiye edilmiştir. Bu model Şekil 1'de sunulmuştur. Etkin bir teorik altyapıya sahip olan TKM, uyarlanabilirliği, basitliği, doğruluk ve sağlamlığı nedeniyle, teknoloji kabulünü ölçmek için şimdiye kadar en yaygın kullanılan modellerden biri haline gelmiştir (AlEmran ve diğerleri, 2018; Estriegana, Medina-Merodio ve Barchino, 2019; Lin, Fofanah ve Liang, 2011, s. 2; Lin ve diğerleri, 2011, ss. 271-273; Liu ve diğerleri, 2014; Salloum, Alhamad, Al-Emran, Monem ve Shaalan, 2019). TKM; ABD, KSA, Kore, Çin gibi birçok ülke de, e-alışveriş, e-posta, mobil alışveriş, E-ticaret, mobil öğrenme, E-öğrenme, E-devlet, mobil devlet, bilgisayar, çevrimiçi kütüphaneler, cep telefonları, dijital kütüphaneler ve veri tabanları gibi çeşitli alanlarda, çeşitli konularda ve çeşitli bağlamlarda, kullanıcıların bu teknolojileri kabulü ve yeterince kullanıp kullanmadıklarını anlamak ve bu teknolojilerin kabulünü etkileyen faktörleri tanımlamak için yaygın olarak kullanılmaktadır (Çelik ve Sökmen, 2018, s. 79; Rafique ve diğerleri, 2020; Yıldırır ve Kaplan, 2019, ss. 26-27).

TKM'ın, uzun yıllar yaygın olarak kullanılması öğrenciler, tüketiciler, öğretmenler ve diğer tüm kullanıcılar tarafından teknolojinin kabulünü araştırmak için önde gelen bir bilimsel paradigma olarak ortaya çıktığını göstermiştir(Granić ve Marangunić, 2019). Buna ek olarak bu modelin bilişim teknolojilerinin kabul edilmesi ve kullanılmasıyla ilgili en fazla tercih edilen model olduğu görülmektedir (Çelik ve Taş, 2021)

TKM'nin temeli sebepli davranış teorisine dayanmaktadır (Rafique ve diğerleri, 2020, s. 3; Y1ldırır ve Kaplan, 2019, ss. 2627). Sebepli davranış teorisine göre insanların belirli bir davranışı gerçekleştirme niyeti, eylemin temel belirleyicisi olup niyet ise tutum ile öznel normlar tarafindan belirlenmektedir (Topal, Günay, Uğur ve Aydin, 2020, s. 87). Davis sebepli davranış teorisini algılanan fayda, algılanan kullanım kolaylığı, niyet, kullanıcı tutumu ve gerçekleşen davranışlar arasındaki ilişkileri analiz ederek bireylerin teknolojiyi benimsemesini açıklamak için kullanmıştır (Davis, 1989). TKM nedensel bağlantıların bir dizi inanç, tutum, niyet ve davranışa bağlı olarak gerçekleştiğini teorileştirmektedir. Bir bireyin gerçek sistem uygulama gibi teknolojik araçları kullanımını incelemek için, çoğu çalışma, bireyin sistemi kabul etme niyetini etkileyen faktörlere odaklanmaktadır (Lin ve diğerleri, 2011, ss. 272-273).

Önceki araştırmalar, algılanan kullanışlılığın ve algılanan kullanım kolaylığının, bir kullanıcının teknoloji kabulünü belirleyen iki etkili faktör olduğunu göstermektedir (Lin ve diğerleri, 2011). TKM'nin temel amac1; mümkün olan en az değişken sayısıyla, bilgi sistem(ler)i ve teknolojiyi kullananların davranışlarının, tutumlarının ve teknolojiyi benimsemelerinde etkili olan faktörlerin teorik açıdan doğrulanmış model yardımıyla çözülebilmesidir (Davis, 1989; Yıldırır ve Kaplan, 2019, ss. 26-27). TKM, bireylerin teknoloji tercihlerinin belirlenmesi, bireylerin teknoloji kullanımına gösterdikleri direnç nedenlerinin açıklanması, gerçekleşen değişimlere verebilecekleri tepkilerin ortaya koyulabilmesi gibi amaçlarla geliştirilmiştir (Uğur ve Turan, 2016, s. 103). TKM'da algılanan kullanışlılık/fayda ve algılanan kullanım kolaylığı, teknolojiyi kullanma niyetini doğrudan etkilemektedir. Ayrıca, algılanan 
fayda, algılanan kullanım kolaylığından doğrudan

etkilenmektedir (Joo, Park ve Lim, 2018, s. 51).

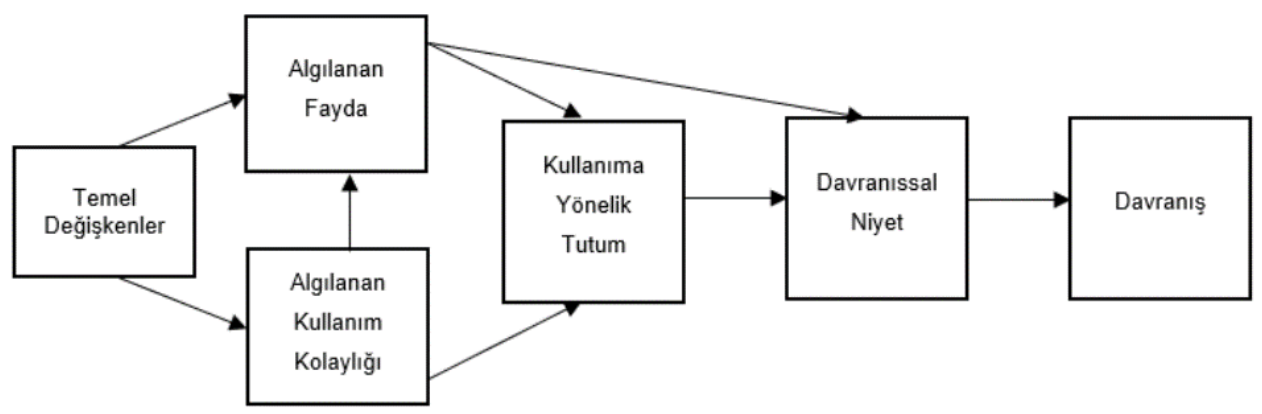

Kaynak: Davis, F. D., Bagozzi, R. P. ve Warshaw, P. R. (1989). User Acceptance of Computer Technology: A Comparison of Two Theoretical Models. Management Science, 35(8), 982-1003.

\section{Şekil 1 Teknoloji Kabul Modeli}

\section{Yöntem}

$\mathrm{Bu}$ bölümde öncelikle önerilen model ve araştırma hipotezlerine değinilmiştir. Devamında ampirik metodolojiye yer verilmiş̧ir. Bölümün sonraki kısmı araştırmada elde edilen sonuçlara ayrılmıştır ve bu sonuçlar yorumlanmıştır. Araştırmaya ait veriler 1 Şubat 2019 ve 30 Nisan 2019 tarihleri arasında toplanmıştır. $\mathrm{Bu}$ çalışmada kullanılan ölçekler, konu ile ilgili önceki çalışmalardan uyarlanarak elde edilmiş̧ir. Algılanan kullanım kolaylığı ve algılanan fayda ve ögeleri Davis (1989)'dan uyarlanmıştır. Sistem kalitesi ve bilgi kalitesi ve ölçekleri Bailey ve Pearson (1983), Delone ve McLean (1992) ve Baroudi ve Orlikowski (1988)'den elde edilmiş̧ir. Kişilerarası etki ve diş etki Bhattacherjee (2000)'den uyarlanmıştır. Tatmin ölçeği Oliver
(1980) ve Spreng ve ark. (1996)'dan uyarlanmıştır. Devam etme niyeti ölçeği ise Mathieson (1991) ve Bhattacherjee (2001)'den uyarlanmıştır. Cevaplar 5'li likert ölçeği ile alınmıştır. (1=Kesinlikle Katılmiyorum, 2=Katılmiyorum, 3=Kısmen Katılıyorum, 4=Katılıyorum, 5=Kesinlikle Katılıyorum şeklinde).

\section{1. Önerilen Model ve Araștırma Hipotezleri}

$\mathrm{Bu}$ araştırmada E-devlet sisteminin kullanan kullanıcıların tatminini anlamak amaciyla, tatminin olası belirleyicileri olarak çeşitli özellikler ele alınarak bir araştırma modeli önerilmektedir. Modelin temel varsayımı, E-devlet sisteminden memnuniyetin algılanan kalite ve algılanan kullanılabilirlik ve kişisel norm tarafindan belirlendiğidir. Önerilen araştırma modeli Şekil 2'de gösterilmektedir.

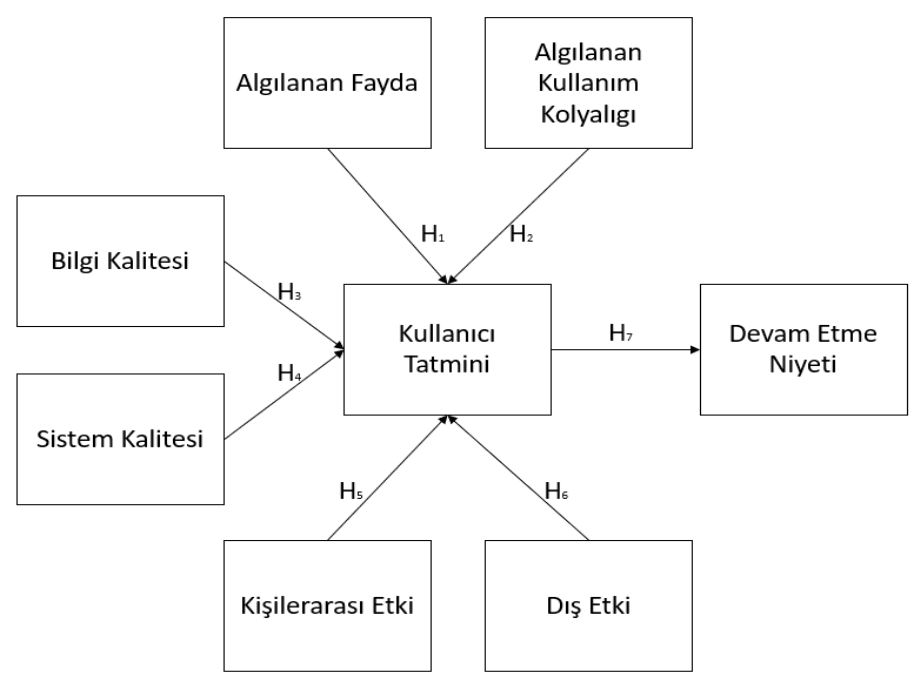

Şekil 2. Önerilen araştırma modeli 
Etimologlar, satisfaction sözcüğünün, latince satis (yeterli, kâfi) ve facere (başarmak-sağlamak) köklerinden türetilmiş bir kelime olduğunu ifade etmektedir. Basit anlamda, kelimenin kökleri dikkate alındığında, ürün ya da hizmet tatmininin temel tanımı, yeterliliğin arandığı noktanın sağlanması olarak ifade edilmektedir (Çelik, 2021). Literatürde müşteri tatmini, müşteri sadakatinin ana belirleyicisi olarak görülmüş ve pazarlamacilar ve araştırmacılar tarafindan müşteri sadakatine yol açan başlıca faktörler keşfetmeye çalışılmıştır (Rezaei ve Amin, 2013). Kullanıcı tatmini ilgili yapılan çalışmalar da bu çabaların sonucudur. Yapılan bu çalışmalar değerlendirildiğinde algılanan fayda değişkeni tatmin değişkeni üzerinde pozitif ve anlamlı etkiye sahip olduğu görülmektedir. (Natarajan, Balasubramanian ve Kasilingam, 2017) tarafından yapılan çalışmada bireylerin, mobil alışveriş uygulamalarının alışveriş performanslarını arttırdığına ve kendilerine fayda sağladığına inandıklarında, bu uygulamalara karşı olumlu tatmin duygusu geliştirdiği sonucuna ulaşılmıştır (Natarajan, Balasubramanian ve Kasilingam, 2017). Yine benzer biçimde Cep telefonu kullanıcılarının Mobil web sitelerine yönelik çalışmada algılanan fayda değişkeni tatmin değişkeni üzerinde pozitif etkiye sahip olduğunu ortaya koymuştur (Amin, Rezaei ve Abolghasemi, 2014). Literatürdeki çalışmalar değerlendirildiğinde algılanan fayda değişkeni tatmin değişkeni üzerinde pozitif ve anlamlı etkiye sahiptir. Literatürdeki bu çalışmalar dikkate alınarak aşağıdaki hipotez oluşturulmuştur.

H1: Algılanan faydanın, E-devlet sistemi kullanıcılarının tatmini üzerinde anlamlı ve pozitif bir etkisi vardır.

(Amin ve diğerleri, 2014)'nin tarafindan yapılan Cep telefonu kullanıcılarının Mobil web sitelerine yönelik tutumlarının değerlendirildiği çalışmada Algılanan kullanım kolaylığının değişkeni kullanıcılarının tatmini değişkeni üzerinde pozitif etkiye sahip olduğunu ortaya konmuştur (Amin ve diğerleri, 2014). Literatür değerlendirildiğinde algılanan fayda değişkeni tatmin değişkeni üzerinde pozitif ve anlamlı etkiye sahiptir. Literatürdeki bu çalışmalar dikkate alınarak aşağıdaki hipotez oluşturulmuştur.

H2: Algılanan kullanım kolaylığının, E-devlet sistemi kullanıcılarının tatmini üzerinde anlamlı ve pozitif bir etkisi vardır.

Mobil hizmetler hem eğlence hem de iş dünyasında günlük yaşamda giderek daha büyük bir yer edinmekte ve büyük kolaylıklar sağlamaktadır (Koivumäki, Ristola ve Kesti, 2008). (Koivumäki ve diğerleri, 2008) tarafından gerçekleştirilen bilgi kalitesinin farklı boyutlarının tüketicilerin mobil bilgi hizmetlerine yönelik tatmini ve nihayetinde bu hizmetlerin kabulünü nasıl etkilediğine odaklandığı çalışmada, bilgi kalitesinin boyutların hem faydacı hem de hedonik kullanım bağlamlarında tüketici tatminini nasıl etkilediği analiz edilmiştir. Sonuçlar, tüm bilgi kalitesi boyutlarının kullanıcı tatmini ile istatistiksel olarak anlamlı bir pozitif ilişkiye sahip olduğunu göstermektedir. Kullanıcı tatmininin de bir hizmeti tekrar kullanma niyeti ile pozitif bir ilişkisi vardır. Sonuçlar ayrıca içeriğin hedonik hedefleri olan kullanıcılar için daha önemli olduğunu göstermektedir. (Song, Migliaccio, Wang ve Lu, 2017) tarafindan gerçekleştirilen çalışmada bilgi kalitesinin tüketici tatmini üzerinde anlamlı bir pozitif etkiye sahip olduğunu göstermiştir. (C.-C. Lin, Wu ve Chang, 2011) tüketici tatmini bilgi kalitesinden pozitif ve anlamlı olarak etkilenmektedir. Ayrıca (DeLone ve McLean, 1992) gerçekleştirdiği çalışmada bilgi kalitesinin tüketici tatmini üzerinde anlamlı etkiye sahip olduğunu gösteren birçok çalışmayı sunmuştur. Literatürdeki bu çalışmalar dikkate alınarak aşağıdaki hipotez oluşturulmuştur.

H3: Bilgi kalitesinin, E-devlet sistemi kullanıcılarının tatmini üzerinde anlamlı ve pozitif bir etkisi vardır.

(C.-C. Lin ve diğerleri, 2011) tarafından gerçekleştirilen çalışmada sistem kalitesinin tüketici tatmini üzerinde anlamlı bir pozitif etkiye sahip olduğunu göstermiştir. Benzer biçimde (Nirwanto ve Andarwati, 2019) tarafindan gerçekleştirilen çalışmada sistem kalitesinin tüketici tatmini üzerinde anlamlı bir etkiye sahip olduğunu göstermiştir. Ayrıca (DeLone ve McLean, 1992) gerçekleştirdiği çalışmada sistem kalitesinin tüketici tatmini üzerinde anlamlı bir etkiye sahip olduğunu gösteren birçok çalışmayı sunmuştur. Literatürdeki bu çalışmalar dikkate alınarak aşağıdaki hipotez oluşturulmuştur.

H4: Sistem kalitesinin, E-devlet sistemi kullanıcılarının tatmini üzerinde anlamlı ve pozitif bir etkisi vardır.

(Hsu ve Chiu, 2004) tarafında yaptığı çalışmada elde edilen bulgular, e-hizmet devam niyeti için kişilerarası etkinin önemini doğrulamakta ve ilk benimsemeden sonra, kişilerarası etki, ehizmet kullanımından memnuniyet duygusu üzerinde daha güçlü bir etki yapacağını ortaya koymuştur. Literatürdeki bu çalışmalar dikkate alınarak aşağıdaki hipotez oluşturulmuştur.

H5: Kişilerarası etkinin, E-devlet sistemi kullanıcılarının tatmini üzerinde anlamlı ve pozitif bir etkisi vardır.

Kişilerarası etki, arkadaşlar, meslektaşlar ve üstler tarafından ağızdan ağıza etkiyi ve kişisel bilgileri belirtirken, dış etki, kitle iletişim raporlarını, uzman görüşlerini ve bir davranışı gerçekleştirirken bireyler tarafından dikkate alınan diğer kişisel olmayan bilgileri göstermektedir. (H.-F. Lin, 2007; Ruiz-Mafe, Tronch ve Sanz-Blas, 2016; Zhou, 2017). (Hsu ve Chiu, 2004) tarafindan yapılan çalışmada olduğu gibi bazı çalışmalarda kişilerarası etkinin, memnuniyet üzerinde dış etkenlerden daha güçlü bir etkiye sahip olduğunu gösterilmiştir (Roca, Chiu ve Martínez, 2006). Yapılan başka bir çalışmada ise kişilerarası etkinin memnuniyeti etkileyen faktörlerden biri olduğu tespit edilmiştir (Çelik ve Sökmen, 2018b). Ancak, E-devlet kullanıcı tatminine yönelik bilgimizi geliştirmek ve bu değişkenlerin ilişkisinin incelenmesinin literatüre katkı sunacağını düşündüğümüz için bu ilişkiyi incelemeyi öneriyoruz ve aşağıdaki hipotezi yapıyoruz:

H6: Dış etkinin, E-devlet sistemi kullanıcılarının tatmini üzerinde anlamlı ve pozitif bir etkisi vardır.

(Koivumäki ve diğerleri, 2008) tarafından gerçekleştirilen bilgi kalitesinin farklı boyutlarının tüketicilerin mobil bilgi hizmetlerine yönelik tatmini ve nihayetinde bu hizmetlerin kabulünü nasıl etkilediğine odaklandığı çalışmada, kullanıcı tatmininin bir hizmeti tekrar kullanma niyeti ile pozitif bir ilişkisi olduğu sonucuna ulaşmışlardır. Sonuçlar ayrıca içeriğin hedonik hedefleri olan kullanıcılar için daha önemli olduğunu göstermektedir. (Rezaei ve Amin, 2013) tarafından gerçekleştirilen ve odak noktasını, Malezya'daki üniversite öğrencilerinin çevrimiçi yeniden satın alma niyetinin öncüllerini araştırdığı çalışmada tahminin, yeniden satın alma niyetinde pozitif anlamlı olarak etkili olan faktörler arasında yer aldığ sonucuna ulaşılmıştır. (Agrebi ve Jallais, 2015) Kullanıcı tatmininin tekrar kullanmayı olumlu etkilediğini bulmuşlardır. Literatürdeki bu çalışmalar dikkate alınarak aşağıdaki hipotez oluşturulmuştur. 
H7: Kullanıcı tatmininin, E-devlet sistemi kullanıcılarının sistemi kullanmaya devam etme niyeti üzerinde anlamlı ve pozitif bir etkisi vardır.

\subsection{Amprik Metodoloji}

Önceki bölümde belirtilen hipotezleri test etmek amaciyla Edevlet sistemi kullanıcılarına bir anket uygulanmıştır. Bahsi geçen anket Google Formlarda oluşturulmuş ve bir ankete ait bir link elde edilmiştir. Elde edilen anket linki E-devlet sistemi kullanıcılarına farklı elektronik iletişim yollarıyla ulaştırılmıştır. Bunun neticesinde 1427 anket verisi elde edilmiştir ( $N=1427)$. Bu çalışmada demografik bilgilerin oluşturulması, doğrulayıcı faktör analizi ve yapısal eşitlik modeli analizi R programı ile yapılmıştır. Çalışmada R programının kullanılmasının sebebi R'ın güçlü bir istatistiksel analiz aracı olmasıdır (Çelik ve diğg., 2018).
Araştrımada kullanılan ölçeklerin güvenilirlikleri ve korelasyon matrisinin oluşturulması için ise SPSS 18 programı kullanılmıştır.

\subsection{Veri Analizi ve Araştırma Bulguları}

Araştırma modelini test etmek için kullanılan veriler E-devlet sistemi kullanıcılarına çevrimiçi anket oluşturularak uygulanmıştır. Araştırmanın amacı ve kimler tarafından yapıldığını açıklayan ve içinde demografik bilgiler, algılanan fayda, algılanan kullanım kolaylığı, bilgi kalitesi, sistem kalitesi, kişilerarası etki, dış etki, kullanıcı tatmini ve devam etme niyeti ölçeklerinden meydana gelen kapsamlı bir anket oluşturulmuştur. Yapılan araştırmaya katılan bireylere ait demografik veriler Tablo 1'de gösterilmektedir.

Tablo 1. Katılımcılara ait demografik bilgiler

\begin{tabular}{|c|c|c|c|}
\hline & Gruplar & Frekans & Yüzde \\
\hline Cinsiyet & Erkek & 561 & 39.4 \\
\hline \multirow{4}{*}{ Yaş } & $18-23$ aras1 & 869 & 60.9 \\
\hline & $31-37$ aras1 & 64 & 4.5 \\
\hline & $38-45$ aras1 & 62 & 4.4 \\
\hline & 46 ve üzeri & 37 & 2.5 \\
\hline Medeni Hal & Bekar & 1178 & 82.6 \\
\hline \multirow{4}{*}{ Eğitim Durumu } & Lise & 378 & 26.5 \\
\hline & Ön Lisans & 212 & 14.9 \\
\hline & Lisans & 810 & 56.8 \\
\hline & Lisansüstü & 27 & 1.8 \\
\hline Aylık Gelir & 0-1000€ & 820 & 57.5 \\
\hline \multirow{3}{*}{$\begin{array}{l}\text { E-devlete giriş için genellikle } \\
\text { kullanılan cihaz }\end{array}$} & Cep telefonu & 1146 & 80 \\
\hline & Bilgisayar & 253 & 17.7 \\
\hline & Diğer & 28 & 2.3 \\
\hline \multirow{4}{*}{ E-devleti kullanma süresi } & 0 ile1 sene aras 1 & 177 & 12.4 \\
\hline & 1 ile 3 sene aras 1 & 509 & 35.7 \\
\hline & 3 ile 5 sene aras 1 & 354 & 24.9 \\
\hline & 5 sene üstü & 387 & 27 \\
\hline Toplam & & 1427 & 100 \\
\hline
\end{tabular}

Çalışmaya katılan bireylere ait demografik verilerin frekansyüzde dağılımları Tablo 1'deki gibidir. Buna göre cinsiyet dağılımları incelendiğinde katılımcıların \%60,6'sının kadın ( $n=866), \% 39,4$ 'nün ise erkek $(n=561)$ olduğu görülmüştür. Katılımcılar yaş açısından incelendiğinde ise \%60,9'nun $(n=869)$ 18-23 yaşlar arasında, \%27,7'sinin $(\mathrm{n}=395)$ 24-30 yaşlar arasında, \%4,5'unun $(\mathrm{n}=64)$ yaşlar arasında, \%4,4'ünün $(\mathrm{n}=62)$ yaşlar arasında, $\% 2,5$ 'nun ise 46 yaş ve üzerinde olduğu görülmüştür. Medeni hal açısından bakıldığında katılımcıların \%17,4'nün $(n=249)$ evli, \%82,6'sının $(n=1178)$ ise bekar olduğu tespit edilmiştir. Katılımcılar eğitim durumu bakımından ele alındığında $\% 26,5$ 'inin $(n=378)$ lise mezunu, \%14,9'unun $(n=212)$ önlisans mezunu, \%56,8'inin $(\mathrm{n}=810)$ lisans mezunu olduğu, \%1,8'inin $(n=27)$ lisansüstü mezunu olduğu görülmüştür. Aylık gelir durumlarına göre katılımcıların \%57,5'nun (n=820) 0-1000£ aralığında olduğu, \%25,5'nun $(\mathrm{n}=364)$ 1001€-3000€ aralığında olduğu, \%11,7'sinin (n=166) 3001€-5000€ aralığında olduğu, \%5,3'nün ise 5001€ ve üzeri olduğu tespit edilmiştir. Kullanıcıların E-devlet sistemine girişte genellikle kullandıkları cihazlar incelendiğinde \%80'nin $(n=1146)$ cep telefonu kullandığ $1, \% 17,7$ 'nin $(n=253)$ bilgisayar kullandığı, \%2,3'ün $(n=28)$ ise farklı cihazlar kullandığı görülmüştür. Kullanıcıların E-devlet sistemini kullanma süreleri incelendiğinde \%12,4'nün $(\mathrm{n}=177) 0$ ile 1 sene aras1, \%35,7'nin $(\mathrm{n}=509) 1$ ile 3 sene aras1, $\% 24,9$ 'nun $(n=354) 3$ ile 5 sene aras1, \%27'sinin $(n=387)$ ise 5 sene üstünde olduğu tespit edilmiştir. 


\begin{tabular}{l|c|c|c|c}
\hline Uyum indeksi & Değer & İyi uyum değerleri & Kabul edilebilir uyum değerleri & Sonuç \\
\hline Ki kare/sd & $1655.579 / 377=4,39$ & $<3$ & $<5$ & Kabul edilebilir uyum \\
\hline$C F I$ & 0.964 & $>0.97$ & $<0.95$ & Kabul edilebilir uyum \\
\hline$R M S E A$ & 0.049 & $<0.050$ & $>0.080$ & Iyi uyum \\
\hline$T L I$ & 0.958 & $>0.95$ & $>0.90$ & İyi uyum \\
\hline$N F I$ & 0.954 & $>0.95$ & $>0.90$ & İyi uyum \\
\hline$R F I$ & 0.946 & $>0.95$ & $>0.90$ & Kabul edilebilir uyum \\
\hline$R N I$ & 0.964 & $>0.95$ & $>0.85$ & İyi uyum \\
\hline$G F I$ & 0.924 & $>0.90$ & $>0.85$ & İyi uyum \\
\hline$A G F I$ & 0.906 & $>0.90$ & $>0.90$ & Iyi uyum \\
\hline$I F I$ & 0.964 & $>0.95$ & & Iyi uyum \\
\hline
\end{tabular}

Çalışmaya ait uyum iyiliği değerleri Tablo 2'de gösterilmiştir. Çalışmada incelen uyum iyiliği indisleri şunlardır: Ki kare uyum testi / Serbestlik derecesi (X2/sd), Karşılaştırmalı Uyum İndeksi (CFI-Comperative Fit Index), Yaklaşık Hataların Ortalama Karekökü (RMSEA-Root Mean Square Error of Approximation), Normlaştırılmış Uyum İndeksi (NFI-Normed Fit Index), Göreli Merkezi Olmayan İndeks (RNI, Relative Noncentrality Index), Göreli Uyum İndeksi (RFI-Relative Fit
Index), İyilik Uyum İndeksi(GFI, Goodness of Fit İndex), Normlaştırılmamış Uyum İndeksi (TLI -Tucker-Lewis İndeksi), Fazlalık Uyum indeksi (IFI, Incremental Fit Index) ve Düzeltilmiş İyilik Uyum İndeksi(AGFI, Adjustment Goodness of Fit İndex). Sonuçlar incelendiğinde bütün uyum iyiliği değerlerinin kabul edilebilir uyum veya iyi uyum gösterdiği görülmektedir. Buna göre toplanan veriler ile önerilen modelin uyumlu olduğunu söylenebilmektedir.

Tablo 3. Cronbach alpha, AVE, CR değerleri ve korelasyon matrisi

\begin{tabular}{l|c|c|c|c|c|c|c|c|c|c|c}
\hline & $\boldsymbol{\alpha}$ & AVE & $\mathbf{C R}$ & $\mathbf{1}$ & $\mathbf{2}$ & $\mathbf{3}$ & $\mathbf{4}$ & $\mathbf{5}$ & $\mathbf{6}$ & $\mathbf{7}$ & $\mathbf{8}$ \\
\hline $1-A F$ & 0.891 & 0.734 & 0.892 & $(0.856)$ & & & & & & & \\
\hline $2-A K K$ & 0.916 & 0.734 & 0.917 & $0.629^{* *}$ & $(0.856)$ & & & & & & \\
\hline $3-B K$ & 0.912 & 0.677 & 0.913 & $0.649^{* *}$ & $0.627^{* *}$ & $(0.822)$ & & & & & \\
\hline $4-S K$ & 0.883 & 0.574 & 0.889 & $0.544^{* *}$ & $0.600^{* *}$ & $0.731^{* *}$ & $(0.757)$ & & & & \\
\hline $5-K E$ & 0.905 & 0.768 & 0.908 & $0.511^{* *}$ & $0.448^{* *}$ & $0.578^{* *}$ & $0.622^{* *}$ & $(0.876)$ & & & \\
\hline $6-D E$ & 0.842 & 0.647 & 0.846 & $0.509^{* *}$ & $0.468^{* *}$ & $0.615^{* *}$ & $0.659^{* *}$ & $0.708^{* *}$ & $(0.804)$ & & \\
\hline $7-T A T$ & 0.888 & 0.724 & 0.887 & $0.676^{* *}$ & $0.633^{* *}$ & $0.741^{* *}$ & $0.703^{* *}$ & $0.670^{* *}$ & $0.707^{* *}$ & $(0.850)$ & \\
\hline 8-DEN & 0.899 & 0.752 & 0.901 & $0.634^{* *}$ & $0.568^{* *}$ & $0.678^{* *}$ & $0.654^{* *}$ & $0.681^{* *}$ & $0.683^{* *}$ & $0.812^{* *}$ & $(0.867)$ \\
\hline
\end{tabular}

a: Cronbach Alpha Katsayısı; AVE: Ayıklanmış Ortalama Varyans; CR: Yakınsama Geçerliliği; Parantez içindeki değerler AVE değerlerinin kareköküdür; AF: Algılanan Fayda; AKK: Algılanan Kullanım Kolaylı̆̆ı; BK: Bilgi Kalitesi; SK: Sistem Kalitesi; DE: Dış Etki; KE: Kişiler Arası Etki; TAT: Tatmin; DEN: Devam Etme Niyeti; **p $<0.01$

Çalıșmada kullanılan ölçeklerin Cronbach Alfa Güvenilirlik Kaysayısı, Ayıklanmış Ortalama Varyans (AVE-Average Variance Extracted), Kompozit Güvenirlik (CR- Composite Reliability or Construct Reliability) ve korelasyon matrisi Tablo 3'teki gibidir. Buna göre tüm ölçeklerin Cronbach Alpha katsayısının 0.842 ile 0.916 arasında değerler aldığ 1 görülmektedir. Cronbach Alfa katsayısının 0.7'den büyük olması gerekmektedir (Nunally, 1978; Iacabucci ve Duhackek, 2003). Elde edilen sonuçlar ölçeklerin güvenilirliklerin oldukça yüksek olduğu göstermektedir.

Yakınsama geçerliliği için AVE'nin 0.5 'ten yüksek olması ve CR'nin AVE'den büyük olması gerekmektedir (Hair ve diğ., 2010; Fornell ve Larcker,1981). Tablo 3 incelendiğinde AVE değerlerinin 0.574 ile 0.768 arasında değerler aldığı görülmektedir. Dolayısıyla tüm değerler 0.50 'den yüksektir. Ayrıca tüm ölçeklerim CR değerlerinin AVE'den yüksek olduğu görülmektedir. $\mathrm{Bu}$ durum ölçeklerin geçerliliklerinin yüksek olduğunu göstermektedir. Ayrıca ölçeklere ait yapıların ayrışma geçerliliği incelenmiştir. Ayrım geçerliliğinin sağlanabilmesi için AVE değerlerinin kareköklerinin, ilgili değişkenin diğer değişkenlerle olan korelasyon değerinden yüksek olması gereklidir. Her yapı için AVE değerlerinin karekökünün, yapılar arasındaki korelasyondan büyük olduğu Tablo 3'te görülmektedir. $\mathrm{Bu}$ durum ayrım geçerliliğinin sağlandığını göstermektedir (Hair vd., 2010).

Yapılar arasındaki ilişkileri görmek için korelasyon analizi yapılmıştır. Bunun sonucunda tüm yapılar arasında anlamlı $(p<0.01)$ ve pozitif bir ilişki olduğu tespit edilmiştir. Yapılar arasındaki en güçlü ilişsinin Tatmin ile Devam Etme Niyeti arasında $(\mathrm{r}=0.812, \mathrm{p}<0.01)$, en zayıf ilişkinin ise Algılanan 
Kullanım Kolaylığı ile Kişilerarası Etki arasında ( $\mathrm{r}=0.448$,

$\mathrm{p}<0.01$ ) olduğu tespit edilmiştir.

Tablo 4: Yapısal eşitlik modeli analizi

\begin{tabular}{|c|c|c|c|}
\hline Hipotez & $\begin{array}{c}\text { Standardize } \\
\beta\end{array}$ & $\mathbf{p}$ & Desteklenme/Red \\
\hline $\begin{array}{l}\text { H1: Algllanan faydanın, E-devlet sistemi kullanıcılarının tatmini üzerinde anlamlı ve } \\
\text { pozitif bir etkisi vardır. }\end{array}$ & 0.225 & 0.000 & Desteklendi \\
\hline $\begin{array}{l}\text { H2: Algllanan kullanım kolayllğının, E-devlet sistemi kullanıcılarının tatmini } \\
\text { üzerinde anlamlı ve pozitif bir etkisi vardır. }\end{array}$ & 0.115 & 0.000 & Desteklendi \\
\hline $\begin{array}{l}\text { H3: Bilgi kalitesinin, E-devlet sistemi kullanıclarının tatmini üzerinde anlamlı ve } \\
\text { pozitif bir etkisi vardır. }\end{array}$ & 0.220 & 0.000 & Desteklendi \\
\hline $\begin{array}{l}\text { H4: Sistem kalitesinin, E-devlet sistemi kullanıcılarinın tatmini üzerinde anlamlı ve } \\
\text { pozitif bir etkisi vardlr. }\end{array}$ & 0.043 & 0.251 & Reddedildi \\
\hline $\begin{array}{l}\text { H5: Kişilerarast etkinin, E-devlet sistemi kullanicllarının tatmini üzerinde anlaml } \\
\text { ve pozitif bir etkisi vardır. }\end{array}$ & 0.159 & 0.000 & Desteklendi \\
\hline $\begin{array}{l}\text { H6: Dış etkinin, E-devlet sistemi kullanıclarının tatmini üzerinde anlamlı ve pozitif } \\
\text { bir etkisi vardlr. }\end{array}$ & 0.317 & 0.000 & Desteklendi \\
\hline $\begin{array}{l}\text { H7: Kullanicı tatmininin, E-devlet sistemi kullanıcılarının sistemi kullanmaya devam } \\
\text { etme niyeti üzerinde anlamlı ve pozitif bir etkisi vardır. }\end{array}$ & 0.917 & 0.000 & Desteklendi \\
\hline
\end{tabular}

Yapısal eşitlik modeli analizi sonucunda desteklenen ve reddedilen hipotezler Tablo 4'de görülmektedir. Buna göre H1, H2, H3, $\mathrm{H} 5, \mathrm{H} 6, \mathrm{H} 7$ desteklenmiş, $\mathrm{H} 4$ ise reddedilmiştir.

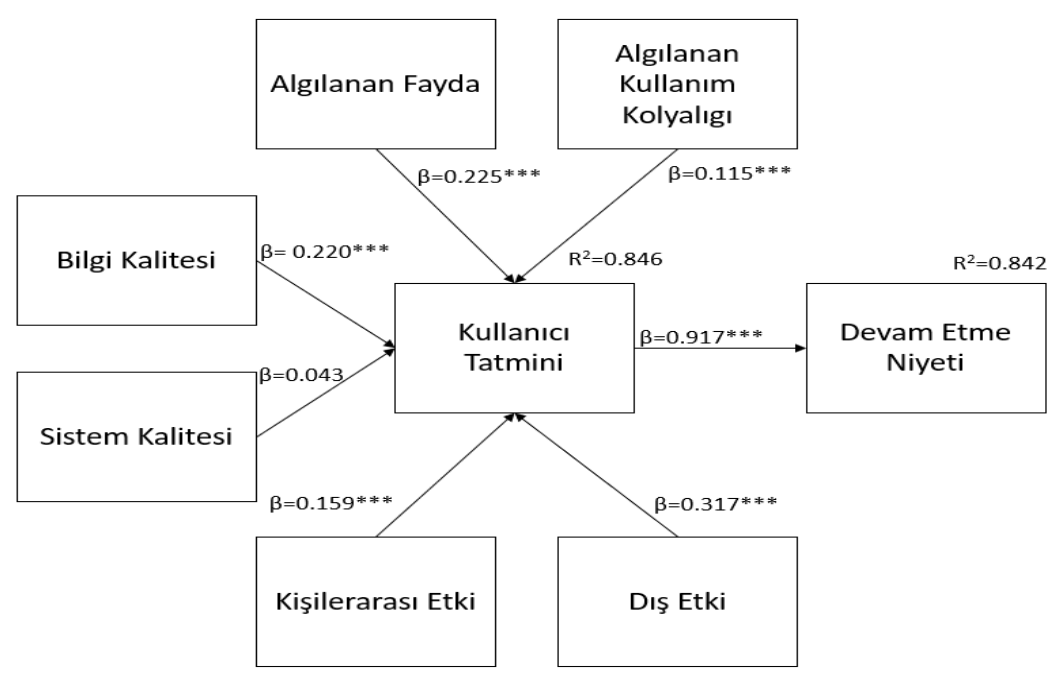

Şekil 3. Yapılar arasindaki standardize $\beta$ katsayılart ve $R^{2}$ değerleri $(* * * p<0,001)$

Değişkenler arasındaki $\beta$ katsayıları ve R2 değerleri Şekil 3'te görülmektedir. Buna göre kullanıcı tatmini \%84.6 oranında (R2=0.846) algılanan fayda, algılanana kullanım kolaylığı, bilgi kalitesi, kişilerarası etki ve dış etki tarafindan açıklandığı görülmektedir. Ayrıca devam etme niyeti \%84.2 (R2=0.842) oranında kullanıcı tatmini tarafından açıklandığı belirlenmiştir.

\section{Sonuç ve Tartışma}

Teknoloji alanında gerçekleşen hızlı değiş̧im ve gelişmeler hayatın her alanında etkisini göstermektedir. Bu değişim ve gelişim devletlere kamu yönetimine dair işlemleri internet üzerinden yapabilme imkânı sağlamıştır. Böylece E-devlet sistemi ortaya çıkmıştır. E-devlet ile kamu hizmetleri daha etkin ve verimli bir biçimde verilebilmektedir. Her geçen gün daha fazla hizmet E-devlet sistemi içerisinde yer almaktadır. Bu sayede vatandaşların E-devlet üzerinden işlemlerini kolaylıkla yapması sağlanmaktadır. Tüm bilgi sistemlerinde olduğu gibi, E-devlet sisteminde de kullanıcıların memnuniyeti ve sistemi kullanmaya devam etme niyetini etkileyen faktörlerin araştırılması önem arz etmektedir.

$\mathrm{Bu}$ çalışmada E-devlet sistemi kullanıcılarının memnuniyetini ve kullanmaya devam etme niyetini etkileyen faktörlerin neler olduğu araştırılmıştır. Bunun için bir araştırma modeli önerilmiş ve E-devlet kullanıcıları üzerinde test edilmiştir. Buna göre e devlet sistemi kullanıcı tatmininin olası belirleyicileri olarak sistem kalitesi, algılanan kullanım kolaylığı, algılanan fayda, bilgi kalitesi, dış etki ve kişilerarası etki belirlenmiştir. 
Bulgular incelendiğinde kullanıcı tatmini üzerinde en fazla etkinin dış etki olduğu görülmektedir. Bu bağlamda E-devlet sisteminde bulunan hizmetlerin bilinirliğinin artırılması gerekmektedir. Bunun için reklamlar yapılmalı, hizmetlerin bireylere faydalarının gösterilmesi önem arz etmektedir. Ayrıca Edevlet sisteminin kamu işlemlerini gerçekleştirmek için iyi bir yöntem olduğuna dair kamu spotları başta olmak üzere yazılı ve görsel basında haberler yapılmalı ve vatandaşların bu konudaki bilgisi artırılmalıdır. Kamu kurumları E-devlet üzerinden sundukları hizmetleri tüm vatandaşlara etkin bir şekilde duyurmalıdır. Bireylere, kamu kurumlarında E-devletin kullanımına ilişkin kitapçık, broşür, bilgilendirme notu gibi dökümanlar dağıtılmalısdır. İnsanların E-devlet sistemine karşı tutumlarını olumsuz yönde etkileyebilecek internette ve sosyal medyada ortaya çıkabilecek yanlış bilgilere karşı idari merciler gerekli önlemleri almalıdırlar.

Kullanıcı tatmini üzerinde etkili en güçlü faktörlerden biri de algılanan faydadır. Bu sonuç Seyhun \& Kurtuldu (2020), Amin vd. (2014) ile Rezaei \& Amin (2013) tarafından yapılan çalışmalarda elde edilen bulgularla benzerlik göstermektedir. Bireyler E-devletin kendileri için ne kadar faydalı olduğunu bilirlerse $\mathrm{o}$ derece memnun olmaktadır. $\mathrm{Bu}$ bağlamda vatandaşların işlemlerini devlet dairesine gitmeden, E-devlet sistemi üzerinden kamu işlemlerini kolaylıkla, haftanın hergünü yirmi dört saat erişerek yapabilecekleri konusunda bilgilendirilmelidir. İnsanlar kamu dairesine bizzat gitmeyi tercih edebilmektedir. Bu konuda vatandaşlar E-devlet sisteminin daha güvenli ve pratik olduğu konusunda bilgilendirilirse, sistemden algıladıkları faydanın derecesi artacaktır. E-devlet üzerinden edinilen bilgi ve belgelerin tüm kurumlar için geçerli olması gerekmektedir. Böylece kurum çalışanlarının iş yükü azalırken vatandaşın işlemleri yapması hız kazanacaktır. Bu durumda hem zaman tasarrufu hem de kâğıt tasarrufu sağlanacaktır.

Bilgi kalitesi kullanıcı tatmini üzerinde anlamlı ve pozitif bir etkiye sahiptir. Elde edilen bu sonuç Koivumäki vd. (2008), Song vd., (2017), Lin vd. (2011) ile Machado-Da-Silva vd., (2014)'nın çalışmalarında ulaştıkları sonuçlarla benzerlik göstermektedir. Buna göre E-devlet sisteminin bilgiyi zamanında, kolay ve eksiksiz bir biçimde ilettiği görülmektedir. Ayrıca bireyler ihtiyacı olan bilgilere gelişen teknoloji yardımıyla E-devlet üzerinden kolaylıkla ulaşabilmektedir.

Kullanıcı tatmini üzerinde etkili bir diğer faktör ise kişilerarası etkidir. Bu sonuç Hsu \& Chiu (2004) tarafından yapılan çalışmada elde edilen bulgularla benzerlik göstermektedir. Buna göre vatandaşlar, çevrelerinde kamusal işlemlerini E-devlet üzerinden çözen bireyler gördüklerinde Edevlet sisteminden memnuniyetleri artmaktadır.

$\mathrm{Bu}$ çalışmada algılanan kullanım kolaylığının kullanıcı tatmini üzerinde en az etkiye sahip olduğu tespit edilmiştir. Amin vd., (2014), Rezaei \& Amin, (2013) ile Seyhun \& Kurtuldu, (2020) tarafindan yapılan çalışmalarda ulaşılan sonuçlarla benzerlik göstermektedir. Yeni teknolojilerin kullanımının kolay olması kullanıcı tatmin duygusunu olumlu etkilemesine karşın zamanla söz konusu teknolojiye alışmayla berber kullanımının kolay olmasının önemi azalarak tatmin duygusu üzerinde belirgin bir etkisi olmadığı (Seyhun ve Kurtuldu, 2020, ss. 617-619) düşünülmektedir.

Lin vd., (2011) ile Nirwanto veAndarwati, (2019) sistem kalitesinin kullanıcı tatmini üzerinde bir etkisinin olduğu sonucuna ulaşmışlardır. Ancak bu çalışmada Song vd., (2017) bulgularıyla benzer biçimde sistem kalitesinin kullanıcı tatminini e-ISSN: 2148-2683 etkilemediği sonucuna varılmıştır. $\mathrm{Bu}$ sonucun vatandaşların mevcut sistemden aldıkları hizmetin hız, kolaylık, hiyerarşik yapı gibi özellikler bakımından beklentilerinin üzerinde olmasından kaynaklandığı düşünülmektedir.

Kullanıcı tatmininin, vatandaşların E-devlet sistemini kullanmaya devam etme niyeti üzerinde anlamlı ve pozitif bir etkisinin olduğu görülmüştür. Bu sonuç Koivumaki vd. (2008), Rezaei \& Amin (2013), Agrebi \& Jallais (2015) ve Çelik \& Sökmen (2018-b) tarafindan yapılan çalışmalarda elde edilen bulgularla benzerlik göstermektedir Kullanıcılar bir sistemden ne kadar memnun olurlarsa o derecede sistemi kullanma alışkanlıkları artmaktadır.

Vatandaşların E-devlet sistemine verdikleri tepkiler doğru algılanmalıdır. Böylece bu tepkilere yönelik ilgili şahıs ve/veya kurumların iyileştirme çalışmaları yapması gerekmektedir. Bireylerin E-devlet sistemi sayesinde alabileceği hizmetlerin neler olduğuna dair tanıtıcı reklamlar ve bilgilendirmeler yapılmalıdır. Bireylerin devlet dairelerine gitmeden E-devlet sistemi üzerinden alabilecekleri hizmetler artırılmalıdır. $\mathrm{Bu}$ tepkilere doğru iyileştirmeler yapılmalı ve E-devletin kullanımı ve kullanmayan vatandaşların kullanması artırılmalıdır.

Gelecek çalışmalarda araştırma modeline gizlilik, güvenlik, tasarruf, yeterlilik, erişilebilirlik gibi boyutlar eklenerek daha kapsamlı sonuçlar elde edilebilir.

\section{Kaynakça}

Acılar, A. (2015). Türkiye'de İşletmeler Sayısal Uçurumun Neresinde? (The Digital Divide in Enterprises in Turkey). Ulusal Yönetim Bilişim Sistemleri Kongresi, sunulmuş bildiri, Erzurum: Social Science Research Network. https://papers.ssrn.com/abstract=2716252 adresinden erişildi.

Agrebi, S. \& Jallais, J. (2015). Explain the intention to use smartphones for mobile shopping. Journal of Retailing and Consumer Services, 22, 16-23. doi:10.1016/j.jretconser.2014.09.003

Akbıyık, A., \& Coşkun, E. (2012). Uzaktan Eğitim Ortamlarında Sosyal Yazılım Kullanımının Kabulünü Etkileyen Faktörlerin Belirlenmesine Yönelik Bir Çalışma. Çankırı Karatekin Üniversitesi Sosyal Bilimler Enstitüsü Dergisi, 3(2), 45-68.

Akçakaya, D. (2017). E-Devlet Anlayışı ve Türk Kamu Yönetiminde E-evlet Uygulamaları. Yüzüncü Yıl Üniversitesi Íktisadi ve Ídari Bilimler Fakültesi Dergisi, (3), 8-31.

Al-Emran, M., Mezhuyev, V., \& Kamaludin, A. (2018). Technology Acceptance Model in M-learning context: A systematic review. Computers \& Education, 125, 389-412.

Amin, M., Rezaei, S. \& Abolghasemi, M. (2014). User satisfaction with mobile websites: The impact of perceived usefulness (PU), perceived ease of use (PEOU) and trust. Nankai Business Review International, 5(3), 258-274. doi:10.1108/NBRI-01-2014-0005.

Bailey, J. E., Pearson, S.W. (1983). "Development of a Tool for Measuring and Analyzing Computer User Satisfaction", Management Science, 29(5), 530-545.

Baroudi, J. J., Orlikowski, W. J. (1988). A Short Form Measure of User Information Satisfaction: A Psychometric Evaluation and Notes on Use, Journal of Management Information Systems, 4(4), 44-59. 
Behan, K., Holmes, D. (1990). Understanding Information Technology, Printice Hall, 2nd ed. NY, 1990

Bhattacherjee, A. (2000). Acceptance of Internet Applications Services: The Case of Electronic Brokerages, IEEE Transactions On Systems, Man, and Cybernetics-Part A: Systems and Humans, 30, 411-420.

Bhattacherjee, A. (2001). An Empirical Analysis of the Antecedents of Electronic Commerce Service Continuance, Decision Support Systems, 32(29), 201-214.

Çelik K., Özköse, H. \& Güleryüz, S. (2018). R ile Yapısal Eşitlik Modeli, Avrasya Sosyal ve Ekonomi Araştırmaları Dergisi, 5(10), 38-48.

Çelik, K. \& Sökmen, A. (2018a). Algılanan Performansın EÖğrenme Kullanıcılarının Memnuniyetleri Üzerindeki Etki. Journal of Turkish Studies, 13(21), 73-92. https://doi.org/10.7827/TurkishStudies.13574

Çelik, K. \& Sökmen, A. (2018b), Uzaktan Eğitime Devam Etme Niyetinin Anlaşılması: Genişletilmiş Teknoloji Kabul Modeli, Yönetim, Ekonomi ve Pazarlama Araştırmaları Dergisi, 2(3), ss. 1-23, DOI: 10.29226/TR1001.2018.21

Çelik, K. \& Taş, A. (2021), E-Ticarette Mobil Alışveriş Uygulamalarını Kullanmaya Devam Etme Niyetinin Araştırılması: Genişletilmiş Teknoloji Kabul Modeli, Üçüncü Sektör Sosyal Ekonomi Dergisi, 56(3), 1997- 2019.

Çelik, K. (2021), The Effect of E-Service Quality and After-Sales E-Service Quality on E-Satisfaction, Bmij, 9(3): 1137-1155, doi:https://doi.org/10.15295/bmij.v9i3.1898

Davis, F. D. (1986). A technology acceptance model for empirically testing new end-user information systems: Theory and results (Doctoral dissertation). MIT Sloan School of Management, Cambridge, MA.

Davis, F. D. (1989). Perceived Usefulness, Perceived Ease of Use and User Acceptance of Technology, MIS Quarterly, 13(3), 319-340.

Davis, F. D., Bagozzi, R. P., \& Warshaw, P. R. (1989). User Acceptance of Computer Technology: A Comparison of Two Theoretical Models. Management Science, 35(8), 982-1003.

DeLone, W. H. \& McLean, E. R. (1992). Information Systems Success: The Quest for the Dependent Variable. Information Systems Research, 3(1), 60-95.

Demirhan, Y., \& Türkoğlu, İ. (2014). Türkiye'de E-devlet Uygulamalarının Bazı Yönetim Süreçlerine Etkisinin Örnek Projeler Bağlamında Değerlendirilmesi. Uluslararası Yönetim İktisat ve İsletme Dergisi, 10(22), 235-256.

Doğan, K. \& Ustakara, F. (2013). Kamuda Bir Yapılanma Dönüşümü Olarak E-Devlet ve E-Yönetişim İlişkisi Üzerine. Global Journal of Economics and Business Studies, 2 (3), 111. Retrieved from http://dergipark.org.tr/gumusgjebs/issue/7489/98694

Elbahnasawy, N. G. (2014). E-Government, Internet Adoption, and Corruption: An Empirical Investigation, World Development, Volume 57, Pages 114-126.

Estriegana, R., Medina-Merodio, J.-A. \& Barchino, R. (2019). Student acceptance of virtual laboratory and practical work: An extension of the technology acceptance model. Computers \& Education, 135, 1-14.

Granić, A. \& Marangunić, N. (2019). Technology Acceptance Model in Educational Context: A Systematic Literature Review. British Journal of Educational Technology, 50(5), 2572-2593. doi:https://doi.org/10.1111/bjet.12864

Hair, J. F., Black, W. C., Babin, B. J., Anderson, R. E. (2010). Multivariate Data Analysis (7th ed.). Upper Saddle River, NJ: Pearson Education
Hsu, M.-H. \& Chiu, C.-M. (2004). Predicting electronic service continuance with a decomposed theory of planned behaviour. Behaviour \& Information Technology, 23(5), 359-373. doi:10.1080/01449290410001669969

Joo, Y. J., Park, S. \& Lim, E. (2018). Factors Influencing Preservice Teachers' Intention to Use Technology: TPACK, Teacher Self-efficacy, and Technology Acceptance Model. Journal of Educational Technology \& Society, 21(3), 48-59.

Kılıççeken, A. (2019). E-Devlet Uygulamalarının Devlet Üniversiteleri Üzerine Etkileri; Kastamonu Üniversitesi Üzerine Bir Analiz. (Yayımlanmamış yüksek lisans tezi). Karabük Üniversitesi Sosyal Bilimler Enstitüsü, Karabük.

Koivumäki, T., Ristola, A. \& Kesti, M. (2008). The effects of information quality of mobile information services on user satisfaction and service acceptance-empirical evidence from Finland. Behaviour \& Information Technology, 27(5), 375385. doi:10.1080/01449290601177003

Kose, T. (2019). Gender and use of e-government services in Turkey: E-government in Turkey. Içinde Gender gaps and the social inclusion movement in ICT (ss. 130-146). IGI Global.

Kutlu, Ö. ve Sevinç, İ. (2010) An Overview Of The EGovernment Initiatives In Turkey In Respect to The Eu Accession Process, International Journal Of Ebusiness and Egovernment Studies, 2(2), ss. 1-12.

Lai, P. C. (2017). The Literature Review Of Technology Adoption Models And Theories For The Novelty Technology. JISTEM - Journal of Information Systems and Technology Management, 14(1), 21-38. doi:10.4301/S180717752017000100002

Lin, C.-C., Wu, H.-Y. \& Chang, Y.-F. (2011). The critical factors impact on online customer satisfaction. Procedia Computer Science, World Conference on Information Technology, 3, 276-281. doi:10.1016/j.procs.2010.12.047

Lin, F., Fofanah, S. S. \& Liang, D. (2011). Assessing Citizen Adoption of E-Government Initiatives in Gambia: A Validation of the Technology Acceptance Model in Information Systems Success. Government Information Quarterly, 28(2), 271-279. doi:10.1016/j.giq.2010.09.004

Lin, H.-F. (2007). Predicting consumer intentions to shop online: An empirical test of competing theories. Electronic Commerce Research and Applications, Intelligent agents in e-services, 6(4), 433-442. doi:10.1016/j.elerap.2007.02.002

Liu, Y., Li, H., Kostakos, V., Goncalves, J., Hosio, S. \& Hu, F. (2014). An Empirical Investigation of Mobile Government Adoption in Rural China: A Case Study in Zhejiang Province. Government Information Quarterly, 31(3), 432-442. doi:10.1016/j.giq.2014.02.008

Management Association, I. (2020). Open Government: Concepts, Methodologies, Tools, and Applications (4 Volumes) (pp. 1-2581). Hershey, PA: IGI Global. doi:10.4018/978-1-5225-9860-2.

Mathieson, K. (1991). Predicting User Intentions: Comparing the Technology Acceptance Model with the Theory of Planned Behavior, Information Systems Research, 2(3), 173-191.

Naralan, A. (2009). Türkiye'de E-Hazırlık ve E-Devletleşme. Atatürk Üniversitesi İktisadi ve İdari Bilimler Dergisi, 23(1), $1-17$.

Natarajan, T., Balasubramanian, S. A. \& Kasilingam, D. L. (2017). Understanding the intention to use mobile shopping applications and its influence on price sensitivity. Journal of Retailing and Consumer Services, 37, 8-22. doi:10.1016/j.jretconser.2017.02.010 
Nirwanto, N. \& Andarwati, M. (2019). End-user satisfaction as an impact of the system quality, information quality, and top management support, upon the perceived usefulness of technology utilization (ss. 1-18). Osaka Conference Prograrn, sunulmuş bildiri. http://eprints.unmer.ac.id/89/ adresinden erişildi.

Oliver, R. L. (1980). A Cognitive Model for the Antecedents and Consequences of Satisfaction, Journal of Marketing Research, 17, 460-469.

Piotrowski, S. J. \& Borry, E. L. (2009). Transparency and local government websites. In Handbook of research on strategies for local e-government adoption and implementation: Comparative studies (pp. 390-407). IGI Global.

Rafique, H., Almagrabi, A. O., Shamim, A., Anwar, F. \& Bashir, A. K. (2020). Investigating the Acceptance of Mobile Library Applications with an Extended Technology Acceptance Model (TAM). Computers \& Education, 145, 103732.

Rezaei, S. \& Amin, M. (2013). Exploring online repurchase behavioural intention of university students in Malaysia. $J$. for Global Business Advancement, 6(2), 92. doi:10.1504/JGBA.2013.053561

Roca, J. C., Chiu, C.-M. \& Martínez, F. J. (2006). Understanding e-learning continuance intention: An extension of the Technology Acceptance Model. International Journal of Human-Computer Studies, 64(8), 683-696. doi:10.1016/j.ijhcs.2006.01.003

Ruiz-Mafe, C., Tronch, J. \& Sanz-Blas, S. (2016). The role of emotions and social influences on consumer loyalty towards online travel communities. Journal of Service Theory and Practice, 26(5), 534-558. doi:10.1108/JSTP-12-2014-0294

Salloum, S. A., Alhamad, A. Q. M., Al-Emran, M., Monem, A. A. \& Shaalan, K. (2019). Exploring Students' Acceptance of ELearning Through the Development of a Comprehensive Technology Acceptance Model. IEEE Access, 7, 128445128462.

Schopf, J. C. (2020). The Governance Effects of Korea's Leading E-Government Websites. Içinde Open Government: Concepts, Methodologies, Tools, and Applications (ss. 20402057). IGI Global.

Seyhun, S. \& Kurtuldu, G. (2020). Genişletilmiş Teknoloji Kabul Modeli Bağlaminda Mobil Alişveriş Uygulamalarinin Benimsenmesini Etkileyen Faktörler. Trakya Üniversitesi Sosyal Bilimler Dergisi, 22(1), 599-628. doi:10.26468/trakyasobed.617630

Song, J., Migliaccio, G. C., Wang, G. \& Lu, H. (2017). Exploring the Influence of System Quality, Information Quality, and External Service on BIM User Satisfaction. Journal of Management in Engineering, 33(6), 04017036. doi:10.1061/(ASCE)ME.1943-5479.0000549

Sökmen, A. \& Çelik, K. (2018). Understanding Distance Education Continuance Intention: Extended Technology Acceptance Model. Journal of Business Management and Economic Research, 2(3), 1-23. https://doi.org/10.29226/TR1001.2018.21

Spreng, R. A., MacKenzie, S. B., Olshavsky, R. W. (1996). A Re-Examination of the Determinants of Consumer Satisfaction, Journal of Marketing, 60, 15-32.

Taytak, M., \& Vural, K. (2019). Bilişim Sistemlerindeki Gelişmelerin Türkiye'de E-Vergi Uygulamaları Üzerine Yansımaları ve Değerlendirilmesi. Finans Politik \& Ekonomik Yorumlar, 56(647), 65-100.

Topal, M. H., Günay, H. F., Uğur, C. Y., \& Aydin, A. (2020). Sebepli Eylem Teorisi Bağlamında Ücretli Poşet Kullanım
Niyeti Üzerinde Etkili Faktörlerin İncelenmesi. Global Journal of Economics and Business Studies 9(17), 22.

TUİK. (t y ). Erişim Adresi: https://www.tuik.gov.tr, Erişim Tarihi 20/.2./2020

TUİK. (t y ). Erişim Adresi: https://www.tuik.gov.tr, Erişim Tarihi 20/.2./2020

Turunç, Ö. (2016). Bilgi Teknolojileri Kullanımının İşletmelerin Örgütsel Performansına Etkisi Hizmet Sektöründe Bir Araştırma. Toros Üniversitesi IIISBF Sosyal Bilimler Dergisi, 3(5), 225-247.

Türkiye Cumhuriyeti Cumhurbaşkanlığı Dijital Dönüşüm OfisiEn Çok Kullanılan Hizmetle. (t y ). Erişim Adresi: https://www.turkiye.gov.tr/cok-kullanilan-hizmetler, Erişim Tarihi: 20.02.2020

Türkiye Cumhuriyeti Cumhurbaşkanlığı Dijital Dönüşüm OfisiEn Çok Kullanılan Hizmetle. (t y ). Erişim Adresi: https://www.turkiye.gov.tr/cok-kullanilan-hizmetler, Erişim Tarihi: 20.02.2020

Uğur, N. G., \& Turan, A. H. (2016). Mobil Uygulama Kabul Modeli: Bir Ölçek Geliştirme Çalışması. Hacettepe Üniversitesi İktisadi ve İdari Bilimler Fakültesi Dergisi, 34(4), 97-126. https://doi.org/10.17065/huniibf.310526

Ural, M. N. (2015). Antik Yunan'da Teknik: Teknoloji Felsefesi Tarihine Genel Bir Bakış. Mavi Atlas, 0(4), 136-144. https://doi.org/10.18795/ma.73791

Yavuz, A. \& Çarıkçı, O. (2009). Bir E-Devlet Hizmeti Olarak EMaliye Uygulamalarının Algılanması: Isparta İli Örneği. Süleyman Demirel Üniversitesi Sosyal Bilimler Enstitüsü Dergisi, (9), 1-28.

Yıldırır, S. C., \& Kaplan, B. (2019). Adoption Of Mobile Application: A Study with Technology Acceptance Model. Kafkas Üniversitesi Iktisadi ve İdari Bilimler Fakültesi Dergisi, 10(19), 22-51. https://doi.org/10.9775/kauiibfd.2019.002

Yildiz, M. (2007). E-Government Research: Reviewing the Literature, Limitations, and Ways Forward. Government Information Quarterly, 24(3), 646-665. https://doi.org/10.1016/j.giq.2007.01.002

Zhang, H., Xu, X., \& Xiao, J. (2014). Diffusion of e-government: A literature review and directions for future directions. Government Information Quarterly, 31(4), 631-636.

Zhou, J. (2017). Exploring the factors affecting learners' continuance intention of MOOCs for online collaborative learning: An extended ECM perspective. Australasian Journal of Educational Technology, 33(5). doi:10.14742/ajet.2914 